\title{
Refreshment and Reunion in Paradise: Near-Death Experiences in Early North African Christianity
}

\author{
Stephen E. Potthoff, Ph.D. \\ Wilmington College, Wilmington, $\mathrm{OH}$
}

\begin{abstract}
While awaiting execution for their Christian faith in a Carthaginian prison in $203 \mathrm{CE}$, the Roman matron Perpetua, along with her companion Saturus, both recorded visions in which they traveled to an otherworldly garden where they experienced spiritual refreshment and were reunited with a divine being and departed companions. Modern scholars have contributed much to recapturing the meaning of these visions by placing them within their wider cultural and psychological contexts. Nevertheless, these scholars have largely overlooked the many characteristics such ancient visions share in common with modern near-death experiences (NDEs) and otherworld journeys cross-culturally. Perpetua and Saturus returned from their otherworld journeys no longer fearing death and able, like modern near-death experiencers, to bring healing, hope, and meaning in the face of death to the community around them. The accounts of their NDEs, passed down for many generations, transformed ancient views and beliefs about the afterlife, a transformation reflected particularly in the construction and decoration of early Christian cemeteries as paradise.
\end{abstract}

KEY WORDS: martyrs; Early Christianity; ancestor cult; near-death experience.

One of the most remarkable documents preserved from Western antiquity is the 1700 -year-old personal diary of a young North African

Stephen E. Potthoff, Ph.D. is Assistant Professor in Religion and Philosophy at Wilmington College in Wilmington, $\mathrm{OH}$. For the present article, he drew from his doctoral dissertation at the University of Minnesota, in which he examined the connection between martyrs' near-death experiences and early Christian ancestor cult in ancient Carthage. Reprint requests should be addressed to Dr. Potthoff at Pyle Box 1203, Wilmington College, 1870 Quaker Way, Wilmington $\mathrm{OH} 45177$; e-mail: Stephen_ Potthoff@wilmington.edu. 
woman named Perpetua. A new mother, a Christian convert, and a martyr, Perpetua met her death in $203 \mathrm{CE}$ during the reign of the Roman emperor Septimius Severus. Perpetua's diary is preserved as part of a larger martyrological account known as the Passion of Perpetua and Felicitas (PP; Musurillo, 1972, pp. 106-131) in which a narrator recorded the experiences of Perpetua and her companions as prisoners awaiting their executions in the Carthage amphitheater. The $P P$ consists of 21 chapters, each with "verse" subsections specified in the original Latin text (Musurillo, 1972); it is these chapters and verses that I reference throughout the following article.

Some of the most fascinating passages from Perpetua's diary record four visions she experienced, all of which in various ways prepared Perpetua for her own imminent death. In the first of these four visions, Perpetua described stepping on a menacing dragon's head, ascending a perilous bronze ladder affixed with all manner of sharp instruments, and emerging in an immense garden. Surrounded by thousands of people clad in white, she was welcomed by a gray-haired shepherd who offered her a mouthful of milk he was drawing, after which she awakened with the taste of something sweet still in her mouth, secure in the knowledge that she would soon leave this life.

Perpetua received her second vision soon after being condemned to death. Having watched her father beaten because of her refusal to sacrifice on behalf of the emperor, Perpetua parted from both her birth family and her newborn child. A few days later, while in prayer, she peered into the postmortem realm and saw Dinocrates, her longdeceased brother, still suffering from the facial cancer he had while alive, and straining to drink from a pool of water whose rim was too high for him to reach. Immediately, she was moved to pray for him, and in a third vision saw Dinocrates now healed of his disease, drinking from a bottomless, gold-rimmed pool, after which he began to play.

After an account of Perpetua's fourth vision, in which she became a man and defeated an Egyptian gladiator in combat, the $P P$ includes a vision that an imprisoned companion of Perpetua, named Saturus, reported. In his account, Saturus described leaving his body in the company of Perpetua and four angels. Gently ascending away from the world into an intense light, they emerged in a garden full of cypress trees, rose bushes, and all manner of flowers. Soon, they were reunited with other already deceased martyrs, after which an enthroned whitehaired man, surrounded by many elders, greeted them. Perpetua and 
Saturus then met with other members of their church family and were even called upon to settle a dispute between a bishop and presbyter. Echoing Perpetua's experience receiving the shepherd's sweet milk, Saturus reported that all present in this paradisal garden were sustained by an indescribably delicious aroma.

Beginning with Augustine of Hippo, the visions of Perpetua and Saturus have inspired a wide variety of interpretations from theological, historical, and psychoanalytic perspectives (Rousselle, 1987, pp. 194-197; Shaw, 1993, pp. 36-42). Modern studies, such as Joyce Salisbury's (1997) excellent book Perpetua's Passion and the Jungian analysis by Marie-Louise Von Franz (1980), have done much to recapture the meaning of these visions by relating them not only to their wider cultural and symbolic context but also to the individual psychological issues and struggles of the martyrs themselves. More recently, Jan Bremmer (2002) analyzed the visions of Perpetua and Saturus within his broader investigation of the roots and evolution of beliefs about the afterlife in Greco-Roman and Christian antiquity (pp. 57-64). Yet, though Bremmer devoted a chapter to ancient and modern near-death experiences (NDEs), he made only brief and passing mention of the visions of Perpetua and Saturus (pp. 96, 97, 99).

Contemporary analysts have operated predominantly from a particular interpretive paradigm whereby they have labeled and treated these ancient visions as dreams in the broadest sense without, for the most part, exploring what might be distinctive about them in both ancient and modern contexts. In my own analysis, I picked up where other scholars have left off, seeking to illuminate the numerous features these ancient visions share in common with modern NDEs. Far from being ordinary dreams, the visions of Perpetua and Saturus profoundly transformed not only the visionaries themselves but also the entire community of Christians who continued to experience the deceased martyrs as a living, healing presence in their midst.

\section{The Visions of Perpetua and Saturus as Ancient NDEs}

Though the visions of Saturus and Perpetua can be fully understood only within their own cultural context, they nevertheless share a significant number of traits in common with modern NDEs. As is the case with most modern NDEs, Perpetua and Saturus received their visions in a physical condition close to death and regarded their 
visionary journeys as divine in nature. Additional similarities include an experience of separation and travel away from the body or earth, an otherworldly destination, a reunion with those who have died before, a meeting with a central divine being, and an experience of profound transformation in the face of death that inaugurates the visionary in a new and special role as healer with a semi-divine status.

The first similarity to note between these ancient and modern NDEs is that they occur in circumstances of extreme physical distress that bring individuals close to death, both physically and psychologically. As Carol Zaleski has observed, NDEs share much in common crossculturally with shamanic and similar "otherworld journeys" in which, during extraordinary states of consciousness associated with physical distress, the spirit is understood to leave the body and travel in the spirit world $(1987$, p. 163; 1996, p. 23). Lakota shaman Black Elk's Great Vision for his people, an extensive otherworld journey out of the body he experienced at nine years of age, was preceded, like many initiatory shamanic visions, by serious illness during which he was "almost the same as dead" (Eliade, 1964, p. 33; Neihardt, 1932, pp. 18, 39-40). Modern American NDEs are frequently reported by those who have come close to death as defined by our own culture. Often, American near-death experiencers return from "clinical death," a state defined by the cessation of heartbeat and respiration, a drop in blood pressure and body temperature, and so on (Moody, 1975, pp. 147-148; Morse \& Perry, 1990, p. 25). However a culture might define death, though, near-death experiencers enter special or altered states of consciousness in which they come face to face with the wider meaning of their own deaths and lives (Zaleski, 1987, p. 164).

As prisoners awaiting their own executions, Perpetua and Saturus found themselves near death, physically as well as psychologically. Robin Lane Fox (1986) has noted that the conditions of darkness, starvation, and sleeplessness in ancient Mediterranean prisons assured that visions abounded among early Christian martyrs-to-be (pp. 400-401). Early on in her diary, Perpetua wrote of the terror she felt, never having been in such darkness before $(P P, 3.5)$, and made special note of the rare instances in which her captors released her and her companions briefly from the prison to refresh themselves $(P P$, 3.7). Not long before her execution, Perpetua complained to the military tribune of the prisoners' poor health $(P P, 16.3)$. Right after being tossed by an enraged cow in the arena, Perpetua was described explicitly by the narrator of the account as being in an ecstatic trance 
state: She was "awakened from a kind of sleep" (quasi a somno expergita), having been in spiritu et in extasi $(P P, 20.8)$.

Although the anonymous author of the $P P$ and the martyrs themselves regarded their visions as divine in origin, writers in the wider ancient Mediterranean region held a variety of opinions on the nature and origins of dreams. Following Aristotle, Cicero, for instance, saw dreams as arising within the mind or soul of the dreamer, derived ultimately from memories of waking experience (De Divinatione 2.128, in Miller, 1994, p. 44). In his Oneirocritica, Artemidorus, dream researcher par excellence of the $2^{\text {nd }}$ century, wavered in his opinion as to whether dreams came from inside or outside the dreamer's mind, though he assigned absolute authority to dreams in which the gods appear (Miller, 1994, p. 82). Closer to home for Perpetua and Saturus, the early church father Tertullian ( $3^{\text {rd }}$ century A.D./1976), on the other hand, in his treatise On the Soul, classified dreams as coming from the soul, the Devil, or God (Salisbury, 1997, p. 95).

For her own part, Perpetua unequivocally understood her dreams as coming from God. Those awaiting martyrdom quite often received dreams and revelations that were accepted as prophetic, always originating in God (Salisbury, 1997, p. 97). Like those who sought out dreams from Asclepius and other healing gods in the ancient practice of incubation, Perpetua also requested and received a vision from God (Von Franz, 1980, p. 16). When introducing the accounts of her first, second, and third visions, she employed the phrase et ostensum est mihi hoc ("and this was revealed to me"), emphasizing the external, divine origin of her visions and her own experience as recipient $(P P$, 4.2). As Jacqueline Amat (1985) has noted, ostensio, the noun form of ostendere, seems in ancient sources to describe "a striking scene, close to prodigious, that manifests divine power" (p. 68) and serves as a vehicle of revelation (Miller, 1994, p. 151). Echoing Perpetua's brother's description of her first vision, the narrator described Saturus's vision as visio, a term similar to ostensio which designated a prophetic dream (Miller, 1994, p. 151; PP, 4.1, 11.1).

Saturus and Perpetua would have rejected the suggestion that their visions were merely the product of mental activity in their own souls. For both martyrs, their visions were ultimately authoritative as revelations of divine reality and truth, more real, or at least as real, in fact, as waking life. Perpetua underscored the reality and authenticity of her first vision in noting that she woke up still tasting the milk curds the shepherd figure had offered her. Some 50 years later, the 
narrator of the Passion of Marian and James would write with regard to these North African martyrs' otherworldly visions: "O sleep more intense than all our waking hours! How happily he sleeps this sleep who is awake by faith" (Pass. SS Mariani et Iacobi, 7.5, in Musurillo, 1972, pp. 204-205).

Like Perpetua and Saturus, modern near-death visionaries view their experiences as qualitatively distinct from ordinary dreams and more real even than waking life (Zaleski, 1996, p. 67). Raymond Moody (1975) noted that near-death visionaries describe their experiences "not as dreams, but as events which happened to them" (p. 176). Psychiatrist and near-death visionary George Ritchie, whose extraordinary otherworld journey to various hellish and heavenly realms originally inspired Moody to write Life after Life, emphasized that "this experience was the most entirely real thing that's ever happened to me" (Ritchie \& Sherrill, 1978, p. 16).

The divine and "ultimately real" nature of NDEs is assumed by the ever-growing ranks of NDE researchers as well. In his insightful and pioneering comparative study of NDEs and UFO encounters, Kenneth Ring concluded that both phenomena represent encounters with what French Islamic scholar Henry Corbin labeled the imaginal realm (Ring, 1992, pp. 220-221). Not to be confused with mere imaginative fantasy, the imaginal realm is "ontologically real" with its own supersensory form, dimensions, and entities (p. 221). Lying "beyond both fantasy as such and the physical world," the imaginal realm is apprehended not through the five senses but in extraordinary states of consciousness where the human imagination functions much like an "organ of perception" (pp. 220-221).

As Zaleski (1987) noted, modern near-death visionaries find themselves, like Perpetua and Saturus, surrounded by a believing community of supportive listeners who validate their experiences against the claims of modern Ciceronian reductionism (pp. 148, 155156). Ring joined many other researchers in citing the profound transformative effects of these experiences in people's lives as the most compelling evidence of their authenticity and divine nature (Valarino, 1997, p. 135). "When we come to examine the core of full NDEs," Ring wrote, "we find an absolute and undeniable spiritual radiance. The spiritual core of the NDE is so awesome and overwhelming that the person who experiences it is at once and forever thrust into an entirely new mode of being" (Ring, 1984, p. 50). Ring saw NDEs ultimately as vehicles not only of personal transformation but also as working to 
bring about "an evolutionary thrust toward a higher consciousness for all humanity" (Valarino, 1997, p. 147).

Another striking feature Perpetua's and Saturus's visions share in common with modern near-death accounts are experiences of passage or travel. Perpetua's experience of passage, in which she treaded upon a dragon's head and ascended a perilous ladder, points to her own martyrdom as well as her victory over death. The frightening or at least unpleasant nature of this passage experience characterizes many modern NDEs as well. One of Moody's (1975) informants spoke of traveling through a long dark place that was like a sewer, whereas others reported drifting through darkness (pp. 30-34).

Unlike Saturus and many modern near-death visionaries, however, Perpetua made no reference to actually leaving her body. Indeed, her experience seems significantly more corporeal in nature: She used her feet to step on the dragon's head and climb the ladder, and she awoke after eating the cheese with the taste of something sweet still in her mouth. As Zaleski (1987) has noted, in modern accounts, there seems to be a roughly even division between those who describe themselves during the visionary journey as possessing an "airy or ethereal body" and those who speak simply of "me" without resort to "elaborate somatic analogies" (p. 117).

In contrast to Perpetua, Saturus echoed many modern accounts when he described leaving his body behind and being carried by four angels gently upward toward an intense light. In modern NDEs, the most well-known mode of passage is through a tunnel with a light at the end (Moody, 1975, pp. 30-34, 62). One of Moody's (1975) informants, though, described sailing in a boat toward the far shore of a body of water (p. 74), and Osis and Haraldsson (1977) recorded the visions of a woman in India who rode a cow to heaven and of an American woman who took a taxicab (pp. 153, 163).

Angelic psychopomps and other guides are common to medieval European NDEs and are known in many shamanic cultures as well (Eliade, 1964, pp. 85, 93). In his Great Vision, the Lakota shaman Black Elk was taken to the teepee of his Grandfathers in the sky by two men bearing spears of lightning (Neihardt, 1932, pp. 18-19).

The visions of Perpetua and Saturus are also strikingly similar to modern NDEs in their descriptions of the otherworld landscape and inhabitants. Perpetua described her otherworldly destination as spatium immensum horti (the immense open space of a garden) ( $P P$ 4.8). Jacqueline Amat (1985) imagined here an open prairie reminis- 
cent of the Isles of the Blessed that Lucian, in his True Histories 1.2, described as a meadow full of flowers (p. 119). Like Perpetua, Saturus emerged after his journey in a heavenly garden that he described as a viridarium filled with rose bushes, all manner of flowers, and cypress trees (PP 11.5). A more specific term than hortus, viridarium designated a type of ornamental park filled with trees and flowers that was planted around villas as well as tombs and temples (Amat, 1985, p. 124).

In modern NDEs, though cities, universities, monasteries, and other settings are also encountered, meadows and gardens are a recurrent feature in accounts from both the United States and India (Brinkley \& Perry, 1994, p. 29; Osis and Haraldsson, 1977, pp. 162, 178; Ritchie \& Sherrill, 1978, p. 69). Echoing the account of a man in India who died and went to a "beautiful garden ... which I cannot describe" (Osis \& Haraldsson, 1977, p. 180), American near-death visionary Betty Eadie, in her book Embraced by the Light, recounted visiting a garden filled with trees and flowers the colors of which were far more intense than anything on earth. "The flowers," she wrote, "are so vivid and luminescent with color that they don't even appear to be solid" (Eadie \& Taylor, 1992, pp. 78-79).

As illustrated by Eadie's account, in many ways the most remarkable aspect of these otherworld landscapes are the vivid sensory and affective experiences associated with them. Perpetua wrote of thousands of people dressed in white garments, Saturus of the immense light (lucem immensam) of the garden awaiting him, the singing cypresses, and the choir chanting endlessly "Holy, holy, holy!" $(P P 4.8 ; 11.4 ; 11.6 ; 12.2$ ).

Although beautiful music is sometimes noted in modern NDEs, the experience of an unearthly, all-encompassing light, Zaleski (1987) concluded, constitutes "one of the few truly 'core' experiences that cut across historical and cultural boundaries" (p. 125). In his study of pagan and early Christian views of the afterlife as reflected in grave inscriptions, Bremmer (2002) observed that whereas light is occasionally mentioned in pagan epitaphs describing the hereafter, "literally dozens of Christian funerary epitaphs speak of heaven as a lux vera, a lux perpetua, an expression which has even been incorporated into the Christian liturgy" (p. 60). Conversely, the senses of taste and smell figure much more prominently in ancient NDEs than in modern ones. Perpetua awoke still tasting the cheese curds she had received, and Saturus wrote of everyone being nourished by an indescribable fragrance (odore inenarrabili alebamur) (PP 13.8). 
In addition to entering and being rejuvenated in unearthly gardens, both ancient and modern near-death experiencers have encountered central divine beings. Black Elk met the Six Grandfathers of his people, and Eadie, whose mother was a Sioux Indian, met Jesus Christ (Eadie \& Taylor, 1992, p. 42; Neihardt, 1932, p. 21). Like many other modern American near-death experiencers, Dannion Brinkley, who was temporarily struck dead by lightning, wrote simply of the "Being of Light" (Brinkley \& Perry, 1994, p. 11; Moody, 1975, pp. 58-64).

As the central divine figure in their visions, both Perpetua and Saturus encountered in the middle of the heavenly garden a whitehaired man (hominem canum), though like many modern near-death experiencers, they never actually identified this divine figure by name ( $P P 4.8 ; 12.3$ ). There are also noteworthy differences in the two descriptions. Whereas Perpetua reported an elderly shepherd milking sheep, Saturus described the white-haired man in regal terms: He was seated on a throne surrounded by an entourage of elders and angels, and four of the angels had to lift Saturus up so that he could greet the man with a kiss.

Given that neither Perpetua nor Saturus identified the white-haired man by name, this figure's identity remains somewhat ambiguous. Ancient Christian audiences might easily have identified the shepherd figure as Christ, God, or both. Similarly, an enthroned figure, whom the angels in Saturus's vision referred to as Dominum, the Lord, could be understood not only as God or Christ but even as a deceased apostle or church elder ( $P P$ 11.10). Such ambiguity or fluidity of identity is characteristic of the "Light" or "Being of Light" reported in many modern American NDEs as well: Visionary images of the divine often go beyond established religious or cultural categories and conceptions, making them at once vibrant, compelling, and challenging of set ideas.

For both Perpetua and Saturus, as well as for modern near-death visionaries, the encounter with the divine being represented a return to source, a coming home. Referring to the elders in Saturus's vision who told him and Perpetua to "go and play" (PP 12.6), Robin Lane Fox (1986) noted: "In the next life, the martyr expected to return to a childlike peace and a harmless simplicity of heart" (p. 403). For both Saturus and Perpetua, visiting the heavenly garden reunited them with their wider Christian family and community. Whereas Saturus met other martyrs who had passed on, Perpetua was reunited with thousands of the faithful dressed in white. The shepherd then greeted Perpetua as a kind father. "Welcome, my child," he exclaimed (PP 4.9). 
As Salisbury (1997) pointed out, the sweet milk curds Perpetua then received would have reminded her of the rites that signaled her initiation and belonging in the family of the Christian faithful, both on earth and in the beyond. Newly baptized church members celebrated their first Eucharist by receiving milk and honey as a foretaste of the "sweetness of heaven," and Carthaginian worshippers consumed milk and cheese in church as a regular part of Holy Communion (p. 103). In the ancient mystery religions as well, milk was, for obvious reasons, the drink of the spiritually reborn (Von Franz, 1980, p. 33). Thus, just as Perpetua had been nursing her own infant, so now the shepherd offered her milk of the newly born, embodying a striking combination of paternal and maternal attributes.

For modern near-death visionaries as well, the encounter with the divine being represents a homecoming, a return to childlike innocence. Describing her reunion with Christ, Eadie wrote:

I felt an utter explosion of love. It was the most unconditional love I have ever felt, and as I saw his arms open to receive me I went to him and received his complete embrace and said over and over, "I'm home. I'm home. I'm finally home." I felt his enormous spirit and knew that I had always been a part of him, that in reality I had never been away from him. (Eadie \& Taylor, 1992, p. 41)

When Moody asked Dannion Brinkley why, after his near-death vision, he was no longer afraid to die, Brinkley drew on more maternal imagery, explaining: "Living on earth is like being forced to go to summer camp. You hate everyone and you miss your momma. Raymond, I'm going home" (Brinkley \& Perry, 1994, p. 183).

Black Elk, too, was warmly welcomed into the rainbow teepee of the Six Grandfathers, and he saw himself planting a cottonwood tree under which his people, with all their children and animals, would live "like little chickens under the mother sheo's [prairie hen's] wing" (Neihardt, 1932, p. 29). Standing in his vision on the highest mountain, Black Elk then experienced himself and his people as part of the wider family of humanity and totality of all living things. "And while I stood there," he recounted,

I saw more than I can tell and I understood more than I saw; for I was seeing in a sacred manner the shape of all things in the spirit, and the shape of all shapes as they must live together like one being. And I saw that the sacred hoop of my people was one of many hoops that made one circle, wide as daylight and as starlight, and in the center grew one mighty flowering tree to shelter all the children of one 
mother and one father. And I saw that it was holy. (Neihardt, 1932, p. 36)

Echoing many modern near-death visionaries, Black Elk remembered afterward continually feeling "homesick for the place where I had been" (Neihardt, 1932, p. 42).

For both ancient and modern near-death experiencers, the spiritual transformation they undergo in the visionary realm manifests itself both on an individual and communal level once they return. On the level of individual psychology, modern near-death visionaries consistently report and exhibit profound transformation characterized, as Zaleski (1996) summarized, by a "loss of fear of death, newfound zest for everyday life, and renewed dedication to the values of empathetic love, lifelong learning, and service to others" (p. 19).

Assessing the individual transformative effects of NDEs in ancient Carthage is much easier for Perpetua than for Saturus, who offered no interpretation of his visionary experience. Perpetua, like modern neardeath experiencers, returned from her otherworld journey no longer fearing her own imminent death, a transformation that many modern commentators have noted (Amat, 1985, p. 73; Pettersen, 1987, p. 147; Von Franz, 1980, pp. 18-19, 75). To successfully navigate the ladder one of the commonest images, Peter Dronke (1984) noted, for the "shaman's or initiate's means of ascent to heaven" - Perpetua had to conquer her fear of the dragon at the base (p. 7). Non me nocebit, in nomine Iesu Christi ("He will not harm me, in the name of Jesus Christ"), Perpetua exclaimed, and treaded upon the dragon's head ( $P P$ 4.24).

After her fourth vision, in which she overpowered an Egyptian gladiator and stepped on his head, Perpetua awoke with a deeper understanding of her visionary experience: "It was not with wild animals that I would fight", she realized, "but with the devil, but I knew that I would win the victory" ( $P P$ 10.14). In his letter To the Martyrs, Tertullian ( $3^{\text {rd }}$ century A.D./1976) also described martyrdom as a trampling on the devil, equating the devil with a snake or dragon (p. 18; Salisbury, 1997, p. 100). Elsewhere, Tertullian identified fear as the primary weapon of Satan, implying, as Perpetua already knew first-hand from visionary experience, that "victory over the dragon was a victory over fear" (Amat, 1985, pp. 73-74). Like her companion Felicitas who knew that "another will be inside me who will suffer for me," Perpetua could draw courage from the assurance in her fourth vision of Pomponius the deacon who told her: "Do not be afraid. I am here, struggling with you" $(P P 15.6 ; 10.4)$. 
Perpetua's first visionary journey up the ladder of fear to enlightenment, rebirth, and victory over death saw its continuation and consummation in her fourth vision with which it shared many structural and thematic similarities. Just as she had to climb a perilous ladder in her first visionary journey, so then in her fourth vision she had to traverse a path "through rough and broken country" (PP 10.3). She trampled the head of the Egyptian gladiator just as she had trodden upon the dragon's head, but this time she rose into the air without the aid of a ladder, perilous or otherwise. And whereas before she drank the milk of the newly born, so then she received the victorious gladiator's reward, the golden bough of eternal life (Von Franz, 1980, p. 69).

Perpetua's visionary journeys from darkness to light, in which she experienced rebirth and ultimate victory over death, show striking structural and thematic parallels not just with shamanic initiatory visions and modern Western NDEs. They also mirror to a remarkable extent the experiences, what little we know about them, of initiates into the ancient Mediterranean mystery religions. A literary fragment attributed to Plutarch notes that "people who die and people who are initiated go through comparable transformations" (Meyer, 1987, p. 8). Immediately after this intriguing observation follows an account of the initiatory experience, possibly within the Eleusinian mysteries, that could well be describing an NDE, either ancient or modern. Touching on many elements common to both Perpetua's and Saturus's visionary accounts, the author of this fragment recounted the process by which mystery initiation served to conquer the fear of death and instill hope for the next life:

At first there is wandering, and wearisome roaming, and fearful traveling through darkness with no end to be found. Then, just before the consummation (telos), there is every sort of terror, shuddering and trembling and perspiring and being alarmed. But after this a marvelous light (phos) appears, and open places and meadows await, with voices and dances and the solemnities of sacred utterances and holy visions. In that place one walks about at will, now perfect and initiated (memuemenos) and free, and wearing a crown, one celebrates religious rites, and joins with pure and pious people. (Meyer, 1987, p. 9)

Yet, the transformation near-death experiencers undergo manifests itself not only on the hidden stage of their interior lives but also in their exterior lives. After his NDE, Brinkley left his job as a government black operative to care for the dying in hospices and to 
establish centers for the sick and dying that he had seen in his vision. Like Brinkley, Black Elk worked to bring healing to his people by reenacting his visionary experience in the Horse Dance and other ceremonies involving the whole community (Neihardt, 1932, pp. 136148).

Perpetua, too, returned from her first visionary journey with newly gained spiritual wisdom, authority, and power to heal, which she imparted to those around her. Together with her fellow confessors, she interpreted her first vision as prophetic in nature: "We realized," she wrote, "that we would have to suffer, and that from now on we would no longer have any hope in this life" (PP 4.10). In her capacity to heal, however, Perpetua, unlike many other imprisoned martyrs whom Tertullian mentioned, directed her attention not to living Christians who sought purification from their sins but, rather, to her brother Dinocrates who had died years earlier (Fox, 1986, p. 448). After seeing Dinocrates in her second vision suffering and thirsty in a dark place, she prayed, bringing him light and refreshment - in this case water rather than milk - which she herself had just received through her own visionary journey of death and rebirth. Receiving the shepherd's milk thus empowered Perpetua to bring healing and nourishment to her deceased brother, reenacting in visionary form the sort of ritual Perpetua, in observance of Mediterranean ancestral rites in the cemetery, would have carried out at her brother's grave (Potthoff, 2000, pp. 27-28, 56-58; Quasten, 1940, pp. 256-257).

Unlike modern near-death experiencers, both Perpetua and Saturus also continued to remain a healing and divine presence in their own communities in their postmortem existence. The prologue of the $P P$ presents the hearing of the account that early Christians read aloud as a means of communion not only with the deceased martyrs but also with Jesus Christ himself (1.6). The postmortem healing presence of these martyrs has also been documented archaeologically by the practice of burial ad sanctos (burial near martyrs and saints). Thousands of the faithful at the ancient Basilica Majorum in Carthage sought graves as close as possible to the probable graves of Perpetua and her companions (Frend, 1977, p. 25). Underlying this practice was the belief that the martyrs were present simultaneously in paradise and in the grave, available to refresh, purify, and protect all those buried around them (Duval, 1988, pp. 142,145). As is well-known, the healing power of martyrs' relics was thought to extend to the living as well. To quote Peter Brown (1981), through the healing miracles at the 
martyrs' tombs, "the eternity of paradise and the first touch of the resurrection come into the present" (p. 78), making "visible the invisible refreshment of the saints" in heaven (p. 75). The refreshment (Latin refrigerium) of paradise that Perpetua and other martyrs enjoyed in the visionary context had its counterpart in the graveside meals (refrigeria) that early Christians celebrated annually at the tombs of the departed (Potthoff, 2000, pp. 207-208, 222-223; Quasten, 1940, pp. 256-257).

The profound role the NDEs of early Christian martyrs played in shaping views about the afterlife is also apparent in the construction and decoration of early Christian churches throughout the Mediterranean. To enter a Christian basilica was to step into a liminal realm betwixt and between, a sacred space where paradise spilled over into everyday space and time. Surrounding and covering in mosaic form the graves of all the Christian departed were the furnishings of paradise reported by the martyrs who had visited this wondrous realm within the context of otherworld visionary journeys. Stonemasons translated the landscape of the visionary paradise, with its rolling meadows, cypress trees, flowers, fountains, and peacocks, into a funerary landscape of mosaic and marble. The martyrs' near-death visions of paradise, in many ways the imaginal counterpart to the external ritual act of creating a paradisal realm in the cemetery, provided blueprints and images from the spirit realm, which stonemasons sculpted into a culturally-shared sacred landscape where all Christians could experience healing and hope across the boundary of death (Potthoff, 2000, pp. 7, 229; Ring, 1992, pp. 218-222;).

The visions of Perpetua and Saturus, far from being "ordinary" dreams in either ancient or modern contexts, belong within the wider category of powerfully transformative otherworld journeys exemplified by shamanic initiatory visions and modern NDEs. Like traditional shamans and modern near-death experiencers, Perpetua and Saturus came face to face with their own deaths at life's boundary, to return spiritually reborn and transformed. No longer afraid to die, they returned to life to share the light and refreshment of paradise with all those around them - and with many generations to come. Citing such modern visionary phenomena as the appearances of the Virgin Mary at Medjugorje, Fox (1986) aptly noted: "Historians of the early Church have tended to overlook that they, too, are living in this golden age of visions: Encounters and sightings have not yet occurred in scholarly libraries" (p. 376). Whether in the ancient Carthaginian church or the 
modern United States, the powerful and pervasive impact of NDEs has much to teach about dream and visionary experience as a vehicle of transformation and revitalization not only in individual lives but also in wider religious communities and movements as a whole.

\section{References}

Amat, J. (1985). Songes et visions: L'au-delà dans la littérature latine tardive. Paris: Études Augustiniennes.

Bremmer, J. N. (2002). The rise and fall of the afterlife: The 1995 Read-Tuckwell lectures at the University of Bristol. New York: Routledge.

Brown, P. (1981). The cult of the saints: Its rise and function in Latin Christianity. Chicago: University of Chicago Press.

Brinkley, D., \& Perry, P. (1994). Saved by the light: The true story of a man who died twice and the profound revelations he received. New York: Villard.

Dronke, P. (1984). Women writers of the Middle Ages: A critical study of texts from Perpetua to Marguerite Porete. Cambridge, England: Cambridge University Press.

Duval, Y. (1988). Auprès des saints corps et ame: L'inhumation "ad sanctos" dans la chrétienté d'Orient et d'Occident du IIIe au VIle siècle. Paris: Études Augustiniennes.

Eadie, B. J., \& Taylor, C. (1992). Embraced by the light. Placerville, CA: Gold Leaf.

Eliade, M. (1964). Shamanism: Archaic techniques of ecstasy (W. Trask, Trans.). Princeton, NJ: Princeton University Press.

Frend, W. H. C. (1977). The early Christian church in Carthage. In J. H. Humphrey (Ed.), Excavations at Carthage 1976 conducted by the University of Michigan (vol. 3 ). Ann Arbor, MI: Kelsey Museum.

Fox, R. L. (1986). Pagans and Christians. New York: Harper and Row.

Meyer, M. W. (Ed.). (1987). The ancient mysteries: A sourcebook. New York: Harper and Row.

Miller, P. C. (1994). Dreams in late antiquity: Studies in the imagination of a culture. Princeton, NJ: Princeton University Press.

Moody, R. A. (1975). Life after life. Covington, GA: Mockingbird Books.

Morse, M., \& Perry, P. (1990). Closer to the light: Learning from the near-death experiences of children. New York: Villard.

Musurillo, H. (Ed.). (1972). The acts of the Christian martyrs. Oxford, England: Clarendon Press.

Neihardt, J. C. (1932). Black Elk speaks: Being the life story of a holy man of the Oglala Sioux. Lincoln, NE: University of Nebraska Press.

Osis, K., \& Haraldsson, E. (1977). At the hour of death. New York: Avon.

Pettersen, A. (1987). Perpetua - prisoner of conscience. Vigiliae Christianae, 41, 139-153.

Potthoff, S. (2000). Refreshment and reunion in the garden of light: Ancestor cult, otherworld journeys, and the sculpting of paradise in early Christian Carthage. Unpublished Ph.D. dissertation, University of Minnesota. (Dissertation Abstracts International-A 61/03, p. 1029, September 2000)

Quasten, J. (1940). "Vetus superstitio et nova religio": The problem of the refrigerium in the ancient church of North Africa. Harvard Theological Review, 33, 253-266.

Ring, K. (1984). Heading toward omega: In search of the meaning of the near-death experience. New York: William Morrow.

Ring, K. (1992). The omega project: Near-death experiences, UFO encounters, and mind at large. New York: William Morrow. 
Ring, K., \& Valarino, E. E. (1998). Lessons from the light: What we can learn from the near-death experience. New York: Plenum/nnsight.

Ritchie, G., \& Sherrill, E. (1978). Return from tomorrow. Waco, TX: Chosen Books.

Rousselle, R. (1987). The dreams of Vibia Perpetua: Analysis of a female Christian martyr. Journal of Psychohistory, 14, 193-206.

Salisbury, J. E. (1997). Perpetua's passion: The death and memory of a young Roman woman. New York: Routledge.

Shaw, B. D. (1993). The passion of Perpetua. Past and Present, 139, 3-45.

Tertullian (1976). On the soul and To the martyrs. In A. Roberts \& J. Donaldson (Eds.), The ante-Nicene Fathers: Volume 3, Tertullian. Grand Rapids, MI: Eerdmans, (Original work $3^{\text {rd }}$ century A.D.)

Valarino, E. E. (1997). On the other side of life: Exploring the phenomenon of the neardeath experience (M. H. Escobar, Trans.). New York: Insight/Plenum.

Von Franz, M.-L. (1980). The passion of Perpetua (E. Welsh, Trans.). Irving, TX: Spring Publications.

Zaleski, C. (1987). Otherworld journeys: Accounts of near-death experience in medieval and modern times. New York: Oxford University Press.

Zaleski, C. (1996). The life of the world to come: Near-death experience and Christian hope. New York: Oxford University Press. 